\title{
Social Entrepreneurship Teaching-Learning Model Through Garbage Bank Activities Based on Spiritual Experience
}

\author{
Arif Julianto Sri Nugroho ${ }^{1}$, Endang Eko Djati S. ${ }^{2}$, Gunawan Budi Santoso ${ }^{3}$ \\ \{arifjuliantosn72@gmail.com ${ }^{1}$ \} \\ ${ }^{1,2,3}$ Universitas Widya Dharma Klaten, Indonesia
}

\begin{abstract}
Experiential learning is a teaching-learning model where individuals focus on doing real teaching-learning practices in the environment. This study aims to develop a teaching-learning model through experiential learning based on spiritual values in teaching-learning social entrepreneurship in garbage bank activities. The research design used is in the form of experimental research on entrepreneurial training based on spiritual experience, simulation, waste bank practice and evaluation. The activities are done in collaboration with Islamic boarding school of Abdurrahman Bin Auf Klaten and activists for waste Bank in Surakarta city. The materials, both theory and simulation practice are given for two full days in the form of social entrepreneurial spirit: inculcation of a sense of belief in God, fear of God, morality, love of the environment, honest, truthful, trustworthy, smart, discipline, visionary, empathy. The activities continue to garbage bank training and field practice. The results of them show a positive value and are effective where from the results of different samples tests, it is obtained the $t$ statistical value that there are changes before and after the activity. The wider implication is formed in the early stage community of garbage banks in the students' domicile environment.
\end{abstract}

Keywords: Experiential Learning, Spiritual-Entrepreneurship, Social Entrepreneurship.

\section{Introduction}

Pursuing the highest profit in the business is not wrong, but when the ambition to achieve high profits by making others be run at a loss, it will potentially worsen business conditions. This can be taken as an example when there is consumer exploitation that causes consumer loss and natural exploitation that causes environmental damage, these conditions can be a cause for business unsustainability and deviate from the essence of business according to Islamic perspective [1]. At this time many young generations in Indonesia who are concerned with the field of Social Entrepreneurship are needed. Therefore, the social entrepreneurship movement can give young people changes. These changes can be in the form of economic empowerment, increasing community literacy, advocating for health, art to religion [2].

Higher education institutions that have national competitiveness require serious improvements to all elements. In order that teaching-learning held in universities results a superior class by producing independent graduates, having a reputation for driving economic growth, it is important for lecturers to present teaching-learning that is relevant to contemporary challenges, so that the teaching-learning done must be in-context rather than out-context [3]. 
Innovative teaching-learning methods are needed to further arouse entrepreneurial interest among students that are relevant to contemporary challenges. Arends said that the ultimate purpose of learning is "to help students become independent and self-regulated learners" or to help students become independent learners, able to direct themselves.

Growing self-confidence to be successful in becoming a social entrepreneur and supported by experiential learning of relevant spiritual values is applied. Based on the background, a research problem is proposed: "How to form a teaching-learning model based on spiritual experience training as an effort to create social entrepreneurship actors".

\section{Literature Review}

\subsection{Experience-Based Teaching-Learning}

David Kolb is an important figure in the practice of experience-based teaching-learning. According to Kolb learning is not just the reception or transmission of teaching-learning material, but the interaction between teaching-learning material and experiences that mutually transform one another [4].

\subsection{Experience Teaching-Learning Cycle of Kolb's Model}

Kolb bases the experience teaching-learning model on the solution to the problem model of Lewin's version that is widely used in the organization development model. Kolb offers four stages of the experience teaching-learning cycle consisting of [5]: concrete experience, full involvement, reflective observation, reflectively observing the students' experiences from many perspectives, abstract conceptualization, formulating, conceptualizing and integrating observations, students' reflections on experiences into logical theory concepts, and the last active experimentation, trying out (experimenting) theories to make decisions in solving problems.

\section{Research Method}

\subsection{Experimental Research Stage}

\subsubsection{Research Strategy}

The initial stage of this research is in the form of experimental study/action research.

\subsubsection{Place and time of research}

The research location for the experimental study of social entrepreneurial teachinglearning based on spiritual values is Islamic boarding school of Abdurrahman bin Auf Klaten. In further activities, students are required to do an internship with garbage bank activists in Solo City as well as work practices in their respective villages by making an initial model of a garbage bank. The implementation of experimental study started from the beginning of 2019 to May 2019. 


\subsubsection{Data collection technique}

In the exploration stage, data collection techniques used are observation, field practice, internship, work practice, documentation and analysis.

\section{Results of Activities}

\subsection{Spiritual Experience Based Training Activities}

The training activities were carried out at the Islamic boarding school of Abdurrahman bin Auf Klaten for two full days in the form of business knowledge training, mental abilities: provision of Muslim entrepreneurship ethos, problem solving, knowledge of market access, business model formation and problem solving.

The activities were carried out in order in the form of giving classical lectures, question and answer, giving assignments, case studies and role playing by involving professionals. Students play an active role. The presenter inserted a number of brainstorming teachinglearning model and proposal of Business Model Canvas so that new entrepreneurial ideas from students emerged at the activity session.

The materials of entrepreneurial training are divided into three sessions, namely: a) a session of entrepreneurial success inspiration, $b$ ) a session of extraordinary self-potential and a boost to entrepreneurial potential, c) a session of million blessing at work, participants are grateful for the abundance of blessings and the inculcation of a sense of belief in God, fear of God , morality, siddiq (honest), amanah (truthful), tabligh (trustworthy), fathanah (smart), discipline, visionary, empathy and love of the environment.

\subsection{Visiting business and training from the Garbage Bank Supervisor}

The field visit was carried out by getting training in social entrepreneurship practices for garbage bank actors in Solo city.

\subsection{The real practice of a garbage bank business in a student environment}

The work mechanism of the garbage bank includes: sorting garbage, depositing, weighing, recording and transporting. Garbage is divided into organic and non-organic garbage. Organic garbage is recycled by composting so that it decomposes nature. Nonorganic garbage includes glass, can/metal, paper and plastics.

In this activity a measure of success and nonsuccess such as garbage reduction and the amount of money from the sale of certain goods (merchandise) during a sale period was made. Quantification of indicators was carried out in the form of increasing environmental cleanliness, increasing public health and additional income.

\subsection{Evaluation to test Model Effectiveness}

Based on the results of the evaluation it can be concluded that the model of social entrepreneurship training through real practice activities, training in Islamic boarding school and business visit is effective. Assessment activity was carried out before training and after the activities. The effectiveness of teaching-learning is obtained from the feedback results of the quantitative test of student satisfaction questionnaires on the quality of activities. 
The respondent quantitative test of pre-social entrepreneurial activity obtained positive regression equation values. If there is an increase in one unit of pre-entrepreneurial activity, it will increase entrepreneurial interest by 0.722 unit. The correlation value obtained is 0.793 having a moderate influence. From the $t$ test it was obtained the probability of 0.000 meaning that $\mathrm{Ho}$ is rejected $\mathrm{Ha}$ is accepted. This means that the pre-activity variable has a significant influence in fostering entrepreneurial interest. The test result of the determination coefficient amounted to 0.615 , meaning that the pre-activity affects $61.5 \%$ of entrepreneurial interest while $38.5 \%$ is influenced by other factors that have not been studied in the activity.

The respondent quantitative test after the activity obtained a positive regression equation which means that if there is an increase in one unit of activity after the activity, it will increase entrepreneurial interest by 0.835 unit. The correlation value obtained at 0.972 has a very high influence. From the $\mathrm{t}$ test it was obtained a probability of 0.000 which means that Ho is rejected $\mathrm{Ha}$ is accepted. This means that entrepreneurial training activity has a significant influence in fostering the interest of social entrepreneur. The test result of the determination coefficient of 0.942 means that entrepreneurial training activity has an influence of $94.2 \%$ on the growth of interest in social entrepreneurship while $5.8 \%$ is influenced by other factors that have not been studied in the activity.

From quantitative test and field activity, several findings were found that direct practices of social entrepreneurship: have conformity with social entrepreneurial teaching-learning needs, have a positive effect on increasing knowledge, behavioral attitudes and skills and strongly support student social entrepreneurial competencies, can explore, optimize and channel participants' talent potential and interest, have a good impact on the participants, they are interested in disseminating their own social entrepreneurial knowledge to others and having high motivation, responsibility, creativity and high innovation.

\section{Discussion}

Spirituality-based entrepreneurship trainings had been carried out by other researchers such as Hijriah et al. [6] and Yuwono et al [7] and the obtained findings of these activities were effective. The problem that arose in the initial garbage bank activities was the lack of skilled human resources as the managers, the reluctance of some people to collect garbage and competition from used goods businesses that can receive goods at higher purchase prices. This finding is also in accordance with the results of Wulandari's et.al research [8] so that there is a need for evaluations related to follow-up activities.

\section{Conclusion}

From the above discussion some conclusions are drawn as follows:

1. Model of social entrepreneurship training based on innovation-oriented spiritual experience is as a continuous training model system, meaning participants are not only provided with training activities but those concerned must be ready to practice becoming independent social entrepreneur candidates.

2. The social entrepreneurship training model based on spiritual experience developed in experimental research is said to be effective. The effectiveness of activities can be seen from: achieving teaching-learning objectives according to priority goals, having conformity with learning needs, having a positive effect on increasing knowledge, attitudes, behavior and skills. More importantly, they are able to innovate to make the initial garbage bank community in their respective environments. 


\subsection{Suggestion}

From the conclusions obtained, the following suggestions are proposed:

1. Monitoring the garbage bank social entrepreneurship activities for further stages

2. It is necessary to examine the model of social entrepreneurship training on the basis of experience with a multi-disciplinary, multi-model and multi-paradigm approach so that it can contribute to a more diverse range of more robust scientific treasures.

\subsection{Acknowledgement}

Directorate of Research and Development of the Higher Education Technology Research Ministry of Republic of Indonesia for the 2019 Applied Research Scheme Grant.

\section{References}

[1] Hijriah , Hanifiyah Y. Spiritualitas Islam dalam kewirausahaan. Jurnal Tsaqafah, Jurnal peradaban islam, vo 12 No 1 pp 187-2018 ( 2016)

[2] Kompas. Inovasi: Kewirausahaan Inovator Didorong, Nov :14 (2016)

[3] Arends R. Learning to Teach, New York:McGraw-Hill (2007)

[4] Kolb Y Klob D. The learning Way: Meta Cognitive Aspec tof Experiential Learning, Simulating and Gamming, ;40 (3): 297-327 (2002)

[5] Knowles M. The Adult Learner: The Define Classic in Adult Education and Human Resources Development, Houston:Gulf Publishing (1998)

[6] Hijriah. H Y. Spiritual Islam dalam Kewirausahaan, Tsaqafah: Jurnal peradaban Islam vol 12 No 1 pp187-208 (2016).

[7] Yuwono S. Partini. Influence of Entrepreneurship Training On The Growth of Entrepreneurship Interest, Jurnal Penelitian Humaniora, Vol 9 No 2 pp 119-127 (2008)

[8] Wulandari, Dwi. Hadi Utomo Sugeng, Narmaditya Bagus. Waste Bank: Waste Management Model in Improving Local Economy, International Journal Of Energy Economics and Policy, Vol 7 issue 3 pp 36-41 (2017). 